\title{
Methodology for Understanding Indian Culture
}

Jai B. P. Sinha ANd Rajesh Kumar

\begin{abstract}
Methods of understanding cultures, including Indian culture, are embedded in a broad spectrum of sociocultural approaches to human behavior in general. The approaches examined in this paper reflect evolving perspectives on Indian culture, ranging from the starkly ethnocentric to the largely eclectic and integrative. Most of the methods herein discussed were developed in the West and were subsequently taken up with or without adaptations to fit the Indian context. The paper begins by briefly reviewing the intrinsic concept of culture. It then adopts a historical view of the different ways and means by which scholars have construed the particular facets of Indian culture, highlighting the advantages and disadvantages of each. The final section concludes with some proposal about the best ways of understanding the complexity that constitutes Indian cultural reality.
\end{abstract}

\section{Facets of Culture}

There are a large number of definitions of culture (Hofstede 2001). Drawing on their common components, a composite view of culture may posit that the core of a culture consists in the shared assumptions, beliefs and values that the people of a geographical area acquire over generations. Assumptions, beliefs and values serve to establish and reinforce the norms that people (viz. society) adopt to judge what is appropriate behaviour in a particular situation or setting. Assumptions, beliefs, values and norms are intermeshed and mutually interactive; they constitute the directional force behind human behaviour, which creates physical artefacts, social institutions, cultural symbols, rituals and myths. The latter in turn reinforce people's beliefs, norms and value systems and thereby enable the society of which they are part, to maintain cultural continuity (Sinha 2004).

An essential feature of a culture is that its basic assumptions, beliefs and values are historically derived, traditional worldviews, transmitted from generation to generation. These temporal sociocultural links signify the distinctive achievements of a human group, thereby enabling them 
to condition their future actions (Kroeber and Kluckhohn 1951: 181). By implication, culture is adaptive and changing - changing more rapidly and radically at its outer layers - artefacts, institutions and patterns of behaviours - than at its core which is primordial. Major changes in environment compel people to behave differently, to modify and create new artefacts, institutions, myths, rituals, symbols and so on, which then induces them to entertain new norms, beliefs, values and assumptions. The new and the old create varying degrees of disparities, only some of which are mitigated. Others persist to cause diversities; parts of which remain dominant leaving others as relatively marginal (Holden 2002: 27 . The degree and nature of diversities vary from culture to culture - rendering them more or less complex (Triandis 1995).

Indian culture is indeed a complex one. Indian cultural traditions can be traced back at least five thousand years. Immigrations, invasions, colonial rule and modernization have brought with them streams of alien influences, only parts of which were assimilated into the primordial Indian worldviews; the remaining ones coexist withing the overarching Indian worldviews. How these cultural traditions are investigated by various scholars depends to some extent on their own culturally rooted approaches to Indian culture.

\section{The Approaches}

\section{The Culture-Personality Approach}

Early attempts to understand Indian culture had their origins in the culture-personality studies that began in the West in the 1940s (Hsu 1961; Kardiner 1945; Linton 1945). The culture-personality approach combined psychoanalytic methods to interpret adult's behaviour in terms of underlying psychodynamics (which had its roots in childhood experiences) with the anthropological methods of field observations in order to identify the basic personality (Mead 1953), modal personality (Wallace 1952) or national character (Benedict 1946; Mead 1953) of the people of a culture. ${ }^{1}$ It was shown that a culture, by fostering uniform child-rearing practices, shapes the personality structure of its people and that this can be profiled by tapping their projected thoughts and feelings expressed in responses to Rorschach and Thematic Apperception Tests (TAT). Personality was believed to be a replica of a culture to the extent that field observations in a caste, community or tribe were considered an adequate basis upon which to identify the attributes of the modal personality in a culture (Whiting and Child 1953; Wallace 1952). 
Following the culture-personality tradition, a number of Western scholars made field observations of the child-rearing practices, social behaviour, rituals, myths and so on to construct the Indian personality (e.g., Hitchcock and Minturn 1963). Indians, for example, were believed to be authoritarian (Lewis 1962), narcissistic with a weak super-ego (Spratt 1966), obsessive-compulsive, infantile and neurotic (Berkeley-Hill quoted by Hartnack 1987: 242). The core of their personality consists of 'an inner sense of instability and insecurity' to the extent that 'nothing and nobody can be relied upon, not even one's own self' (Carstairs 1971: 54). This insecure and unstable personality was alleged to express itself in poor emotional involvement, callousness towards others especially lesser men, mock hospitality, a supremely self-centred attitude, and utter collapse of self-control in the face of strong emotions (Carstairs 1971: 46).

Interestingly, these samples of Western construction of Indian culture and personality were shared by a number of Indian researchers (Taylor 1948). Narain (1957) examined Indian history, political slavery and child-rearing practices to delineate the following national characteristics of Indians:

- absence of commitment, which at an individual level expresses itself in freely made but unfulfilled promises, and an absence of sustained efforts for realizing collective objectives;

- absence of masculine qualities as a result of and identification with the mother;

- dependence on and distrust of authority because of inconsistent rewards and punishments handed out during childhood;

- inability to handle emotions that are either suppressed or burst into uncontrolled temper tantrums; and above all

- contradictory behaviours that manifest themselves in a 'tremendous gap between ideals and performance. Truth is extolled, but all kinds of falsehood are practised; honesty is valued, but dishonesty is rampant; kindness is virtue, but Indians laugh at others' physical deformity or discomfiture; ... Indians are spiritual, but their greed for material things is insatiable' (Narain 1957: 130).

The values and behaviour which are frequently attributed to Indians, according to a review by D. Sinha (1988), include fatalism, passivity, dependency, paranoid reaction, narcissism, insecurity, anxiety, authoritarianism, submission, indifference to contradictions (i.e., lack of rationality) and so on. The trend of relating personality and culture has continued in India (Nandy and Kakar 1980) and elsewhere (D'Andrade 1990; Lee, McCaulay and Draguns 1999). 


\section{Inferences from Texts and Scriptures}

Running parallel to culture-personality studies is the analysis of the ancient Indian texts and scriptures of a religio-spiritual nature which many Indian and Western scholars viewed as highly indicative of an essential Indian personality and culture. It is interesting to note that their such scholars' descriptions varied; while some delineated many negative attributes; others identified idealistically positive facets of Indian culture. Hsu (1963), for example, posited that while the Chinese are situation-centred, and Americans individual-centred, Indians are supernaturally centred. Lannoy (1971) observed that Indians follow a non-sequential logic whereby actions are judged for their own sake rather than for the effects that they produce (i.e., nishakam karm) and that they do not separate the actual and the ideal. Nakamura reported that Indians engage in fantasizing that is 'free, boundless, and extravagant, and often goes to extreme' (Nakamura 1964: 142).

A number of scholars have drawn on the ancient texts to construct a portrait of Indian culture that is characterized by three major themes, each having its own polar opposite, and a synthesizing mindset that enables people to entertain seemingly incongruent and contrasting thoughts, feelings and action orientations. The three dominant themes are the following: cosmic collectivism, hierarchical order, and spiritual orientation. Cosmic collectivism reflects a worldview that the universe consists of diverse forms of animate and inanimate elements that are compatible as well as conflicting. But they all are interconnected and held together by an underlining sense of unity derived from being parts of the ultimate Reality, the Brahman. Further, the whole cosmos and everything within it is arranged in a hierarchical order of being, where each thing is ranked superior to some and inferior to others. In other words, plants, trees, rivers, insects, birds, animals and human beings are all parts of the cosmic collectivism, and are arranged hierarchically. Animates are superior to the inanimate; human beings are superior to both. Among human beings, hierarchical order is based on castes and within castes on age and gender. Within a human being, the head is superior to the middle parts of the body, which are superior to the feet. The body itself has five layers ranging from the gross body (the lowest) to the subtle body/ soul (atman) (the highest). Even food, weather, states of mind, and all conceivable phenomena have layers of hierarchy, one superior to another. Contrary to the belief in hierarchical order is a school of thought that posits a strong egalitarian worldview (Lokayat tradition). 
Spirituality is built into the Indian psyche (Roland 1988: 294), although animal impulses and material strivings are very much a part of life. Human beings tend to live through and then transcend them by rising on a moral scale that leads to a transformed, healthy (swastha - which means stability for a person), composed and detached mind-set that can maintain a balance between the person and the environment, between body and mind, between the states of mind and so on. Striving for perfection through spiritual pursuits, however, is an individual endeavour that has to follow one's natural temperament and stations in life. In other words, it is essentially individualistic in nature (Paranjpe 1988).

Bhawuk described the way the conflicting demands from contrasting dispositions and orientations are held together in Hindu thought by quoting from one of the philosophical texts, Upanisads,

Wise people of India could partition the world in opposites, then put them together into one whole, and then again partition them. People who have a worldview that can deal with such a system of logic and concepts are likely to choose different problems to study, define problems differently, and then use different methodology to study those problems. (Bhawuk 2003: 11)

The method of differentiating, integrating, differentiating and integrating again requires fine-grained logic that is cultivated through discursive dialogues by those who have acquired the capability through introspection, yogic exercises and meditation. The Hindu method is thus experiential (Paranjpe 1988).

Kumar (2004) concludes that this mode of thinking is rooted in the fundamental principles of Brahmanical idealism. Thus, according to the ancient Indian worldview, people seek to attain the unattainable, and embed their search for the perfect solution in a highly moral approach to problem solving. Indeed, there is some evidence to suggest that Indian managers possess a strong moral orientation (England et al. 1974) and that Indian negotiators often seek to take the high moral ground (Cohen 1997) which often lacks pragmatism.

\section{The Reductionist-Positivist Approach}

Both trends - culture-personality and drawing inferences from texts and scriptures - were critiqued on several grounds. Besides being ethnocentric and sweeping in generalization, they lacked scientific rigour and defied the positivistic paradigm of research. Social sciences adopted a reductionist and positivistic approach in which a complex phenomenon was reduced to its simplest forms, which were operationalized and investigated with precision, accuracy and reliability (Bernard 1957: 72). 
The axiomatic assumption was that a scientific method must be objective, impersonal, quantifiable and preferably manipulable in order to derive universally valid laws (Campbell 1952: 27), although the evidence did not entirely support this assumption (Bhawuk 2003; Churchman 1961; Kuhn 1962).

This reductionist-positivistic approach, when applied to social sciences, tended to cleanse culture from behaviour in order to demonstrate pan-cultural generalizability of the laws and principles of behaviour. The approach was coupled with the belief that all societies, whatever their differing levels of economic development and modernization, evolve in the same direction by adopting Western values, attitudes, habits and lifestyles, and thereby converge into a single pattern characterized by the industrialized cultures of the west (Kerr 1983; Meyer 1970; Weinberg 1969). By the same token, the cultural differences are either temporary or unimportant.

\section{The Human Relations-Oriented Approach}

In tandem with the reductionist-positivistic approach, another method that gained ground and claimed to possess greater potential to help understand human behaviour was the human relations-oriented approach. It drew explicitly on the Western worldviews that all human beings are born equal, and are internally directed, growth oriented and autonomous individuals having unique qualities that can be harnessed by allowing them both the freedom and opportunity to realize their potential.

\section{Methods shared by both approaches}

The human relations approach, along with the reductionist-positivistic approach, relied for its methodology principally on surveys, interviews, and experimentation - or a combination of these - to construct a scientific epistemological model for Western society that could be applied with equal validity to the rest of the world.

Surveys are the most frequently employed method in cross-cultural comparison, particularly in the context of values and managerial practices. Researchers using the survey methodology take care to render the items equivalent in their meaning by back translations; they solicit items at various cultural locations in order to avoid culture-specific biases; and control response-sets by having both positively and negatively worded items.

Interviews, however, have the potential to yield information that is both quantitatively and qualitatively superior by including both respondent and operant questions. While respondent items are structured 
with fixed alternatives, the operant ones raise open issues and allow respondents to express themselves in the way they want and to elaborate their responses further, if necessary. This enables the researcher to understand the dynamics of the relationships between the various aspects of the culture, to relate the qualitative and quantitative data, and to develop cultural profiles which can then be compared with profiles in other cultures.

Experimentation suits the reductionist-positivistic approach because the culturally relevant variables are neatly arranged into independent, dependent and intervening variables, thus allowing the researcher to establish causal relationships between culture and behaviour. Employing these methods in different combinations, a raft of theories and concepts have been advanced to claim universal validity.

Introduced into Indian settings, the theories and concepts were replicated in some but not in other cases (see Pareek 1980, 1981). Initially, inconsistent and unexplained findings were brushed aside and attributed to lack of rigour in research, faulty translation of Western instruments and/or their inappropriate administration, or sampling weakness (D. Sinha 1998). However, the inconsistent findings kept piling up: A participative leader was perceived to be weak because he abdicated responsibility to take decisions; an autocratic leader was effective in some and preferred in some other situations; the distinction between motivators and hygiene factors was proved to be an artefact of methods that Herzberg used; Maslow's Needs Hierarchy did not exactly hold true, T-Groups did not work in many cases, and the socio-technical approach by and large failed to make any impact in Indian management practices (Pareek 1980, 1981).

Modernity, for example (defined in terms of Western values and orientations such as an openness to new experiences; an ability to learn how to exert control over one's environment; high aspirations; respect for personal dignity; rationality in decision-making; low respect for the elderly, including one's parents; political participation; and rights for women) was surveyed in six countries including India and (now) Bangadesh to show how family and kinship cohesiveness and religion prevented people from embracing modernity (Inkeles and Smith 1975). Achievement motivation was recommended for economic growth (McClelland and Winter 1969). J. B. P. Sinha (1968) tested the validity of the theory in an experimental study by creating limited and unlimited resource conditions and manipulating the level of respondents' need for achievement (nAchv). The findings showed that high nAchv respond- 
ents achieved the most in unlimited resource conditions, but created interpersonal conflicts that reduced collective gains in the limited resource conditions. The conclusion was that the theory is valid for the USA but not for a resource-limited country such as India.

The roots of the inconsistent findings was partly located in the use of alien concepts (e.g., caste was equated with race, communalism with anti-Semitism, and untouchables with American Blacks, see Nandy 1974) and was partly methodological (J. B. P. Sinha 1973). The reductionist approach of the West took a narrow microscopic view that could be focused only on the fragments of Indian reality and, and hence, yielded findings that were often trivial and meaningless. Meanwhile, the universal validity of Western theories and concepts in the Indian cultural context proved doubtful.

\section{The Etic Approach}

\section{Cultural Dimensions}

By the 1970s, it was generally realized that culture plays a crucial role in determining human behaviour and that one fruitful methodological strategy might be to adopt an etic approach to identify the dimensions on which cultures vary (Triandis 2000) without positing the superiority of one culture over another. The strategy required (a) to compare and contrast cultures and (b) to show the impact of cultural differences on human behaviour. The two publications, Handbook of Cross-Cultural Psychology (Triandis and Berry 1980) and Culture's Consequences (Hofstede 1980) proved to be landmarks in the plethora of emerging crosscultural studies (Chinese Culture Connection 1987; Diener 1996; Hall 1981; Hofstede 2001; Inglehart 1997; Ronen and Shenkar 1985; Schwartz and Bilsky 1987; Triandis and Bhawuk 1997; Smith et al. 1996).

The etic approach adopts an 'outside view' of individual cultures by delineating dimensions that were considered to be universally applicable. Because most of the studies in this approach were designed and conducted by Western scholars, the dimensions were conceptualized in the Western literature. Cultures in these studies were either located on polar dimensions or clustered into groups. Further, the dimensions were related to various other indices (e.g., individualism was correlated with economic affluence of a country). Not all studies aimed to give detail information about individual cultures. Some that did showed that Indian culture was fairly high on power distance, was inclined towards collectivism and masculinity, was low on uncertainty avoidance (Hofstede 1980), high on context orientation (Hall 1981), high in helping 
behaviour (Levine et al. 2001) and high on vertical collectivism (Triandis and Bhawuk 1997).

The etic approach suffers from a number of limitations. The approach that is started from one culture and 'imposed' on other cultures is likely to turn ethnocentric (Nisbet 1971) and may be guided more by the desire to prove the universality of theories and concepts than by their relevance (D. Sinha 1998). Further, the etics do not always have construct and metric equivalence (Hulin 1987). Construct equivalence means that the concept carries the same meaning and its measurement holds the same relationship in all the sampled cultures. Metric equivalence implies that the individuals having the same score on a dimension, irrespective of the level of their cultures on that dimension, have the same probability of endorsing that dimensions. There was plenty of evidence that neither of the two criteria was always met.

Achievement goals in India, for example, include social concerns such as being a good person, considering the well-being of others, fulfilling one's duties, helping others, and being able to gain affection from elders. They can be realized by such means such as respecting others, helping others, obtaining elders' blessings, observing social codes of conduct and so on (Agarwal and Misra 1989; Misra and Agarwal 1985). Participation of subordinates amounts to being consulted by the superior.

There was also evidence that cultural dimensions neither matched with organizational dimensions, nor predicted organizational practices, nor the behaviour of people in a culture. Indian culture, for example, was rated as collectivist, but Indians were found to be both collectivist and individualist and that they combined collectivist and individualist behaviour and intentions in different ways to suit a situation (Sinha et al. 2001; Sinha et al. 2002).

\section{Ecological Dimensions}

Another limitation of the etic approach is that it derives cultural dimensions by aggregating the self-ratings of individuals belonging to culture. Thus, the approach suffers from the circular logic of deriving dimensions from the responses that they are used to explain. In order to overcome this limitation, Georgas, Vijver, van De and Berry (2004) collected cultural-level information for cross-cultural comparisons of the impact of culture on behaviour. The information pertained to levels of precipitation and temperature, economic affluence (per capita gross national product, daily calorie per capita supply as percentage of requirements, per capita consumption of energy, percentage of popula- 
tion employed in agriculture, industry, and services), education (adult literacy and pupil/teacher ratio), mass media (telephone, radio, TV, and daily newspaper circulation per 1,000 inhabitants), demography (infant mortality, life expectancy at birth, death and birth rates and rate of population increase) and religion.

Viewed from this perspective, India is a continent of over 1 billion people having 16 recognized and over 1,600 other languages and dialects, thousands of castes and tribes, all the major religions (although Hinduism dominates) and ethnic groups of the world, varied geography and climatic conditions, extreme and pervasive poverty, a low human development index, the largest democracy that elevates members of the religious minority to the highest political positions, and so on. According to the World Bank, it is the fourth biggest economy, after the USA, China and Japan on its PPP Index (Purchasing Power Parity Index), with a higher gross national income than that of Germany, Canada and Russia. ${ }^{2}$

\section{Etics that Stimulate Emics}

Despite limitations, the etic approach has been able to stimulate studies that generate more culture-specific, emic, concepts and methods. Triandis (1995) distinguished between contents and process in crosscultural research; the contents being generally more culture-specific than process, the latter being often transcultural and hence etic in nature. For example, reward enhances motivation universally, but determining what constitute the most appropriate and adequate rewards depends on cultural preferences (Mendonca and Kanungo 1990). Encouraging participation on equal terms could be rewarding in an egalitarian culture, whereas nurturing in terms of taking personal care of subordinates and guiding, directing and even reprimanding them may be viewed as motivational in the Indian cultural context. Pandey (1981) found that Indian employees ingratiate themselves with their superiors by employing the techniques of self-degradation, instrumental dependency, name-dropping and aligning their views with changing persons and situations, which can often backfire if deployed as a technique in the West. The deservingness of employees for a promotion in India is judged on the combined bases of merit and seniority (Virmani and Guptan 1991). Kakar (1982) profiled Indian conceptualization of mental health and healing practices by observing the traditional healers and conducting interviews with them. He then placed the profiles in the psychoanalytic framework in order to highlight certain universality in the domains of mental health and healing. Thus, the purely emic approach verged on yielding etic insights. 
Although the capability to realize a composed, stress-free and detached approach to life is experiential and involves yogic exercises and meditation (Bhawuk 2003; Chakraborty, 1987; Paranjpe 1988 among others), the impact of yoga and meditation has been shown by employing experimental as well as survey methods. One review (Orme-Johnson et al. 1997), for example, of over 500 experimental studies conducted in over 200 universities in 33 countries revealed that transcendental meditation helps to expand consciousness, decrease oxygen intake and stress levels, increase basal skin resistance and coherence in EEG, and can even virtually suspend breathing up to one minute. All these are crucial for the health and well-being of people. Similarly, there is empirical evidence that people having strong orientation to nishkam karm (working sincerely without getting preoccupied about outcome) experience less work-related stress (Pande and Naidu 1992) and the traditional construct of three gunas (temperamental qualities) was confirmed in a factor analytic study that showed that while sattva (purity in thoughts and action) and positive rajas (composed of love for fame, passion, and power) had a facilitating effect, tamas (inertia or darkness) and negative rajas (consisting of strife and stress) had a debilitating impact on the work ethic, and on managers' personal effectiveness and organizational effectiveness (Kaur and Sinha 1992).

\section{The Complexity of the Indian Culture}

The multifarious pieces of Indian culture collected through a variety of approaches adopting a whole range of methods reveal the culture to be a highly complex one in which the indigenous perspective still holds a primary position encompassing (Dumont 1970) and enfolding (Schulberg 1968) other cultural traditions. The encompassing and enfolding process first involves distinguishing the people, ideas and things that do not fit into the known cognitive categories and, therefore, creating new categories in order to allow them to retain their distinctive attributes. However, the new categories are placed in the hierarchical order, their locations depending on the functional proximity to the indigenous categories. In other words, deviations of any kind, instead of being totally assimilated or rejected, were allowed to retain their distinctiveness, and were treated somewhat differently, but were still considered to be part of the Indian cultural totality.

Thus, Indians are collectivists, but they also have a well-protected secret self that contains highly individualistic thoughts, feelings and fantasies (Roland 1988) as well as a striving to serve self-interests and 
achieve individual distinctions. Expressed differently, the Indians possess both an 'independent' as well as an 'interdependent self' (Markus and Kitayama 1991). The 'independent self' is associated with a desire to pursue individualistic goals whereas the 'interdependent self' is always concerned with fulfilling the expectations of others. The 'other' is highly evident in the consciousness of the 'interdependent self' and this leads to a preoccupation with fulfilling the obligations of significant others (Higgins 1987). They have strong hierarchical orientation, and yet have reverence for persons with high integrity, altruism and superior human qualities (Roland 1988). Which of the contradictory or incongruent thoughts and actions are invoked depends on the particular context.

Indians place a premium on context sensitivity and the balancing disposition. Contrary to Westerners, they have radar-like sensitivity to the specificities of a situation and the long-range implications of their response to it (Roland 1988; J. B. P. Sinha and Kanungo 1997). They balance their responses by avoiding extremes in action and thought or by incorporating even seemingly opposite ideas in a complex way. Contexts are specified in terms of place (desh), time (kaal) and person (paatra). Public places such as a job evoke different norms and values to private settings such as a family. A crisis-like situation allows people to deviate from the code of conduct or to put in extra-ordinary performance. Personally related friends, family members and relatives are trusted and favoured while strangers (out-group members) are distanced, mistrusted and discriminated against.

\section{Conclusions and Implications for Future Research}

A comprehensive understanding of Indian culture requires a holistic and multi-method approach, integrating both etics and emics. The relative primacy of the etic and emic approaches will depend on the researcher and the aim of the research. Those who are outside India are most likely to adopt an etic approach whereby they compare and contrast Indian culture according to the dimensions, concepts and theories that interest them by employing whatever methods they consider to be most appropriate. However, they need to incorporate emic details in order to flesh out the methodologies that they consider to be universally relevant. Construct and metric equivalence have to be ensured to a reasonable degree. Those who want to start with an emic approach by identifying indigenous concepts, theories and methods will tend to develop holistic profiles that should make sense even to outsiders. This requires qualitative comparison of profiles across cultures. Both will employ the whole 
range of methods that are universally available in the behavioural sciences, the relative salience of which, however, would vary depending on the two approaches.

Methods available in the current Western literature need to be radically adapted to be able to capture the Indian cultural complexity. For example, a serious limitation of a survey is the context-free nature of the items. For context-sensitive Indians, a better approach may be to adopt complex scenarios with a hypothetical person making a choice between alternatives. Respondents give much more reliable information when they adopt the role of informants predicting the response of the hypothetical person or groups in such scenarios, rather than when they selfrate on context-free items. In certain instances, group interviews yield better results because the participants feel free to express their feelings and thoughts, stimulate each other to come up with more information, and express the collectively held view of the social reality. The primary data need to be combined with the secondary source information in order to yield a more integrated picture of the reality.

Dr Jai B.P. Sinha is Professor of Psychology and Management at the Assert Institute of Management Studies, Patna, India, and Dr Rajesh Kumar is Associate Professor of International Business at the Aarhus School of Business, Denmark.

\section{NOTES}

1 While basic personality or national character consisted of characteristics that were attributed to all members of a culture, modal personality was defined as the configuration of the most frequently appearing characteristics in the people of a culture.

2 World Development Indicators Data Base, 2003, World Bank, Washington, DC.

\section{REFERENCES}

Agarwal, R. and G. Misra 1989. 'Variations in Achievement Cognitions: Role of Ecology, Age, and Gender'. International Journal of Intercultural Relations 13: 93-107.

Benedict, Ruth F. 1946. The Chrysanthemum and the Sword: Patterns of Japanese Culture. Boston, Mass.: Houghton Mifflin.

Bernard, C. 1957. An Introduction to the Study of Experimental Medicine. New York, NY: Dover.

Bhawuk, D.P.S. 2003. Science of Culture and Culture of Science:Worldview and Choice of Conceptual Models and Methodology. University of Hawaii at Manoa. Mimeographed.

Campbell, N. 1952. What is Science? New York: Dover.

Carstairs, G. M. 1971.The Twice Born. Bombay: Asia Publishers.

Chakraborty, S. K. 1987. Managerial Effectiveness and Quality of Work Life: Indian Insights. New Delhi: Tata McGraw Hill.

Chinese Culture Connection 1987. 'Chinese Values and the Research for Culture-free Dimensions of Culture'. Journal of Cross-Cultural Psychology 18: 143-74. 
Jai B. P. Sinha and Rajesh Kumar

Churchman, C. W. 1961. Prediction and Optimal Decision: Philosophical Issues of a Science of Values. Englewood, NJ: Prentice-Hall.

Cohen, R. 1997. Negotiating across Cultures: Communication Obstacles in International Diplomacy. Washington DC: US Institute of Peace.

D'Andrade, R. G. 1990. 'Culture and Personality: A False Dichotomy'. In D. K. Jordon and M. J. Swartz (eds), Personality and the Cultural Construction of Society. Toscaloosa: The University of Alabama Press: 145-60.

Diener, E. 1996'. Subjective Well Being in Cross-cultural Perspective'. In H. Grad, A. Blanco and J. Georgas (eds), Key Issues in Cross-cultural Psychology. Lisse, the Netherlands: Swets \& Zeitlinger: 319-30.

Dumont, L. 1970. Homo Hierarchicus. Chicago: University of Chicago Press.

England, G. W., O. P. Dhingra and N. C. Agarwal 1974. The Manager and the Man. Kent, Ohio: Kent State University Press.

Georgas, J., F. van de Vijver and J. W. Berry 2004. 'The Ecocultural Framework, Ecosocial Indices and Psychological Variables in Cross-cultural Research'. Journal of Cross-Cultural Psychology 35 (1): 74-96.

Haire, M., E. E. Ghiselli and L. W. Porter 1966. Managerial Thinking: An International Study. New York: Wiley.

Hall, E. T. 1981. Beyond Culture. New York: Doubleday.

Hartnack, C. 1987. 'British Psychoanalysts in Colonial India'. In M. G. Ash and W. R. Woodward (eds), Psychology in Twentieth Century Thought and Society. Cambridge: Cambridge University Press.

Higgins, E. T.1987. 'Self Discrepancy: A Theory Relating Self and Affect'. Psychological Review 94: 319-40.

Hitchcock, J. and L. Minturn 1963. 'The Rajputs of Khalapur'. In B B. Whiting (ed.), Six Cultures. Studies of Child Rearing. New York: Wiley: 203-362.

Hofstede, Geert 1980. Culture's Consequences: International Differences in Work-related Values. Beverly Hills, CA: Sage.

-2001. Culture's Consequences: Comparing Values, Behaviours, Institutions and Organizations across Nations. Second edition. Thousand Oaks, CA: Sage.

Holden, Nigel J. 2002. Cross Cultural Management: A Knowledge Management Perspective. London: Pearson Education Ltd.

House, R. J., N. J. Wright and R. N. Aditya 1997. 'Cross-cultural Research on Organizational Leadership: A Critical Analysis and a Proposed Theory'. In P. C. Earley and M. Erez (eds), New Perspectives on International Industrial/Organizational Psychology. San Francisco: New Lexington Press: 535-625.

Hsu, F. L. K. (ed.) 1961. Psychological Anthropology: Approaches to Culture and Personality. Homewood, IL: Dorsey Press.

-1963. Clan, Caste and Club. Princeton, NJ: Van Nostrand.

Hulin, C. L. 1987. 'A Psychometric Theory of Evaluations of Item and Scale Translations'. Journal of Cross-Cultural Psychology 18: 115-42.

Inglehart, R. 1997. Modernization and Post-modernization: Changing Values and Political Styles in Advanced Industrial Society. Princeton, NJ: Princeton University Press.

Inkeles, A. and D. H. Smith 1975. Becoming Modern: Individual Change in Six Developing Countries. London: Heinemann Educational.

Kakar, S. 1982. Shamans, Mystics and Doctors. Bombay: Oxford University Press.

Kardiner, A. 1945. The Psychological Frontiers of Society. New York: Columbia University Press.

Kaur, P. and A. K. Sinha 1992. 'Dimensions of Gunas in Organizational Setting'. Vikalpa 17: 27-32.

Kerr, H. C. 1983. The Future of Industrial Societies; Convergence or Continuing Diversity? Cam- 
bridge, MA: Harvard University Press.

Kroeber, A. L. and F. Kluckhohn 1951. 'Culture: A Critical Review of Concepts and Definitions'. Peabody Museum Papers, Cambridge, MA: Harvard University 47(1).

Kuhn, T. S. 1962. The Structure of Scientific Revolutions. Chicago, IL: University of Chicago Press.

Kumar, R. 2004. 'Brahmanical Idealism, Anarchical Individualism and Dynamics of Indian Negotiating Behaviour'. International Journal of Cross Cultural Management : 39-58.

Lannoy, R. 1971. The Speaking Tree: A Study of Indian Society and Culture. London: Oxford University Press.

Lee, Y-T., C. R. McCauley and J. G. Draguns (eds) 1999. Personality and Person Perception across Cultures. Mahwah, NJ: Erlbaum.

Lewis, O. 1962. Village Life in Northern India. New York: Vintage Publishers.

Levine, R. V., A. Norenzayan and K. Philbrick 2001. 'Cross-cultural Differences in Helping Strangers'. Journal of Cross-Cultural Psychology 32: 543-60.

Linton, R. 1945. The Cultural Background of Personality. New York; Appleton-Century-Croft.

Markus, H. R. and S. Kitayama 1991. 'Culture and the Self: Implications for Cognition, Emotion and Motivation'. Psychological Bulletin 98: 221-53.

McClelland, D. C. 1961. The Achieving Society. New York: Van Nostrand.

McClelland, D. C. and D. G. Winter 1969. Motivating Economic Development. New York: Free Press.

Mead, M. 1953. 'National Character'. In A. L. Kroeber (ed.). Anthropology Today. Chicago: University of Chicago Press.

Mendonca, M. and R. N. Kanungo 1994. 'Motivation through Effective Reward Management in Developing Countries'. In R. N. Kanungo and Mendonca (eds), Work Motivation:Models for Developing Countries. New Delhi: Sage: 49-83.

Meyer, A. G. 1970. 'Theories of Convergence'. In C. Johnson(ed.), Change in Communist Systems. Stanford: Stanford University Press: 113-29.

Misra, G. and R. Agarwal 1985. 'The Meaning of Achievement: Implication for a Cross-cultural Theory of Achievement Motivation'. In I. R. Lagunes and Y. H. Poortinga (eds), From a Different Perspective: Studies of Behaviour across Cultures. Lisse: Swets \& Zeitlinger: 250-66.

Nakamura, H. 1964. Ways of Thinking of Eastern People: India, China, Tibet, and Japan. Honolulu: East West Center Press.

Nandy, A. 1974. The Non-paradigmic Crisis in Indian Psychology'. Indian Journal of Psychology 49: 1-20.

Nandy, A. and S. Kakar 1980. 'Culture and Personality'. In U. Pareek (ed.), A Survey of Research in Psychology. Bombay: Popular Prakashan (1):136-67.

Narain, D. 1957. Hindu Character. Bombay: University of Bombay Press.

Nisbet, R. E. 1971. 'Ethnocentrism and the Comparative Method'. In A. Desai (ed.), Essays on Modernization of Underdeveloped Societies, Bombay: Thacker (1): 95-114.

Orme-Johnson, D. W., E. Zimmerman and M. Hawkins 1997. 'Maharshi's Vedic Psychology: The Science of the Cosmic Psyche'. In H. S. R. Kao and D. Sinha (eds), Asian Perspectives on Psychology. New Delhi: Sage: 282-308.

Pande, N. and R. K. Naidu 1992. 'Anasakti and Health: A Study of Non-attachment'. Psychology and Developing Societies 4: 89-104.

Pandey, J. 1981. 'Ingratiation as a Social Behaviour'. In J. Pandey (ed.), Perspectives on Experimental Social Psychology. New Delhi: Concept: 157-85.

Paranjpe, A. C. 1988. 'A Personality Theory According to Vedanta'. In A. C. Paranjpe, D. X. E. Ho and R. W. Ribber (eds), Asian Contributions to Psychology. New York: Praeger: 185-213.

Pareek, U. (ed.) 1980, 1981. A Survey of Research in Psychology. Bombay: Popular Prakashan, Vol. 1 and 2. 
Jai B. P. Sinha and Rajesh Kumar

Roland, A. 1988. In Search of Self in India and Japan: Towards a Cross-cultural Psychology. Princeton, NJ: Princeton University Press.

Ronen, S. and O. Shenkar 1985. 'Clustering Countries on Attitudinal Dimensions: A Review and Synthesis'. Academy of Management Review 10: 435-54.

Schulberg, L. 1968. Historic India, Great Ages of Man: A History of the World Culture Series. Amsterdam: Time-Life International.

Schwartz, S. H. and W. Bilsky 1987. 'Toward a Universal Structure of Human Values'. Journal of Personality and Social Psychology 53: 550-62.

Sinha, D. 1988. 'Changing Perspectives in Social Psychology in India: A Journey towards Indigenization'. Asian Journal of Social Psychology 1: 17-32.

Sinha, D. and R. C. Tripathi 1994. 'Individualism in a Collectivist Culture: A Case of Coexistence of Opposites'. In U. Kim, H. C. Triandis, C. Kagitcibasi, S. C. Choi and G. Yoon (eds), Individualism and Collectivism: Theory, Method and Application, Thousand Oaks,CA: Sage: $123-36$.

Sinha, J. B. P.1968. 'ThenAch/nCooperation under Limited/Unlimited Resource Conditions'. Journal of Experimental Social Psychology 4: 233-48.

Sinha, J. B. P. 1973. 'Methodology of Problem Oriented Research in India'. Proceedings of the $12^{\text {th }}$ International Congress of Applied Psychology, Brussels: 1245-55.

-1993. 'The Bulk and the Front of Psychology in India'. Psychology and Developing Societies 5: $135-50$.

-2004. Multinationals in India: Managing the Interface of Cultures. New Delhi: Sage.

Sinha, J. B. P. and R. N. Kanungo 1997. 'Context Sensitivity and Balancing in Organizational Behaviour'. International Journal of Psychology 32: 93-105.

Sinha, J. B. P. and J. Pandey 1972. 'The Process of Decision Making in Dependence Prone Persons'. Journal of Psychological Researches 16: 35-37.

Sinha, J. B. P., T. N. Sinha, J. Verma and R. B. N. Sinha 2001. 'Collectivism Coexisting with Individualism: An Indian Scenario'. Asian Journal of Social Psychology 4: 133-45.

Sinha, J. B. P., N. Vohra, S. Singhal, R. B. N. Sinha and S. Ushashree 2002. 'Normative Predictions of Collectivist-Individualist Intentions and Behaviour of Indians'. International Journal of Psychology 37: 309-19.

Smith, P. B., S. Dugan and F. Trompenaars 1996. 'National Culture and Values of Organizational Employees'. Journal of Cross-Cultural Psychology 27: 231-64.

Spratt, P. 1966. Hindu Culture and Personality. Bombay: Manaktalas.

Taylor, W.S. 1948. 'Basic Personality in Orthodox Hindu Cultural Patterns'. Journal of Abnormal and Social Psychology 43: 3-12.

Triandis, H. C. 1995. Culture and Social Behaviour. New York: McGraw-Hill.

-2000. 'Dialectics between Cultural and Cross-cultural Psychology'. Asian Journal of Social Psychology 3: 185-96.

Triandis, H. C. and J. W. Berry (eds) 1980. Handbook of Cross-cultural Psychology. Boston: Allyn \& Bacon.

Triandis, H. C. and P. S. Bhawuk 1997. 'Culture Theory and Meaning of Relatedness'. In P. C. Earley and M. Erez (eds), New Perspectives on International Industrial/Organizational Psychology. San Francisco: New Lexington Press: 13-54.

Virmani, B. R. and S. V. Guptan 1991. Indian Management. New Delhi: Vision.

Wallace, A. F. C. 1952. The Modal Personality Structure of the Tuscarora Indians, as Revealed by the Rorschach Test. Washington: Bulletin 150, Bureau of American Ethnology.

Weinberg, I. 1969. 'The Problems of Convergence of Industrialized Societies: A Critical Look at the State of a Theory'. Comparative Studies in Society and History 11: 1-15.

Whiting, J. W. M. and I. Child 1953. Child Rearing and Personality. New Haven, CT: Yale University Press.

World Bank 2003. World Development Indicator Database. Washington, DC. 